\title{
Designing Promotion Strategy of Malang Raya's Tourism Destination Branding through Audio Visual Media
}

\author{
Chanira Nuansa ${ }^{1}$, Suryadi $^{2,3}$, Darsono Wisadirana $^{4}$ \\ ${ }^{1}$ Magister Program of Communication Science, Faculty of Social and Political Science, University of Brawijaya, Malang \\ ${ }^{2}$ Center for Culture and Frontier Studies (CCFS), University of Brawijaya, Malang \\ ${ }^{3}$ Faculty of Administration Science, University of Brawijaya, Malang \\ ${ }^{4}$ Faculty of Social and Political Science, University of Brawijaya, Malang
}

\begin{abstract}
This study examines the suitability concept of destination branding with existing models of Malang tourism promotion. This research is qualitative by taking the data directly in the form of existing promotional models of Malang, namely: information portal sites, blogs, social networking, and video via the Internet. This study used SWOT analysis to find strengths, weaknesses, opportunities, and threats on existing models of the tourism promotion. The data is analyzed based on destination branding's concept indicators. Results of analysis are used as a basis in designing solutions for Malang tourism promotion through a new integrated tourism advertising model. Through the analysis we found that video is the most suitable media that used to promote Malang tourism in the form of advertisements. Videos are able to show the objectivity of the fact that intact better through audio-visual form, making it easier to associate the viewer thoughts on the phenomenon of destination. Moreover, video creation of Malang tourism as well as conceptualized ad is still rare. This is an opportunity, because later models of audio-visual advertisements made of this study is expected to be an example for concerned parties to conceptualize the next Malang tourism advertising.
\end{abstract}

Keywords: Advertise, SWOT Analysis, Malang City, tourism promotion

\section{INTRODUCTION}

This study examines about design of promotion for Malang Raya's tourism destination area. Malang is a diverse area with high tourism potential. Malang Raya stretches in the middle of East Java province with mountainous topography in the northern and lowlands at southern. Various well known tourist destinations in this area, such as: Bromo Tengger Semeru Tourism Park, Wonosari Tea Gardens, Waduk Selorejo, Coban Pelangi, Singosari Temple, Balekambang Beach, Sempu Island, and much more [1].

Local governments actually had a program used to lift the tourism sector. But some programs still can't be maximized yet, thus Malang still need help in determining the proper promotion models which can be widely publicized to general public. Promotion which is now circulating widely in the media is a form of promotion that has not been integrated yet. In other words, each tourism object in Malang Raya has its own promotional models that tend to compete with each other. In fact, an existence of integrated campaign models will be an easier way for government to bring Malang to the better promotion concept [2].

\footnotetext{
${ }^{*}$ Correspondence address:

Chanira Nuansa

Email : chaniranuansa@gmail.com

Address : University of Brawijaya, Jl. Veteran Malang
}

Promotion which had done separately from the internal promotion of tourism object is Word of Mouth (WOM) by the personal/company's blogs in the online media. The use of WOM for promotion was considered quite well because WOM include personal assessment that obtained through direct experience by the researcher [3]. Besides blogs, Malang Raya's tourism promotion is also promoted by websites. Some people also use social networking and videos to introduce Malang Raya's tourism objects. The use of internet to promote the tourism is being mostly used, since the internet is a medium that has a wide range and boarder-less. Proper use of Internet with conceptualized advertising models will be able to deliver the products on a desired goal. Just like any other product, tourism is a commodity that needs concept to be promoted [2]. It aims to introduce the objects widely, so it can raise awareness for those who do not know about the tourism object of Malang Raya yet. That's why then strategy were needed to answers the right advertisements models to get an integrated and well conceptualized for Malang Raya's tourism advertise.

This new promotional model will describe the natural resources and tourism potential within the scope of Malang Raya. Thus, it will able to bring out awareness of potential tourists. This is the repulsion of the efforts to establish the 
concept of destination branding, which is expected to be passed on by the advanced form of related parties.

The aim of this study is to create an advertising model, which according to the Handbook of Tourism and Destination Branding, advertising lies in making the initial level, functions only as a trigger to make potential tourists interested to come to the tourism object [2] of Malang. However, this study did not produce any action at the level of a tour and does not address the ideal strategy to really make potential tourists decided to visit tourism object.

\section{MATERIALS AND METHODS}

This research used descriptive qualitative approach, describe situations and events [4]. The primary data in this study is promotion models of Malang Raya's tourism on the web (internet), and direct documentation studies on Malang Raya's tourism object. Secondary data obtained through the literature studies on books, scientific journals, and previous research.

\section{Data Analysis}

We used SWOT (Strengths, Weaknesses, Opportunities, and Threats) analysis on the previous promotion models covering performance, the used term, visualization of images, the impact to the audience and the suitability of the model with the promoted concept in destination branding. The results of SWOT analysis become the basic in creating new ad model for Malang tourism promotion, i.e. integrated tourism destination branding of Malang Raya.

We expected this model introduce a more representative tourism object of Malang Raya. Promotion concepts used in this study is the suggestion in the form of "advertising model", which "Model" is a specification of the "form" itself.

\section{RESULTS AND DISCUSSION}

\section{Recent Advertisement Media}

This study was expected to produce representative object of Malang Raya's tourism. Ads were chosen for its effectiveness to display, perform, and give overview to the public about information with particular purpose. It also has a complex form and goals that aligned with promoted object of tourism. Generally, the form of ads presentation is non personal information about a product, brand, company, or shop run with certain compensation costs. Advertising has four main functions: (1) to inform the audience (informative), (2) to affect the audience to buy (persuading), (3) to refresh the information that has been received by audience (reminding), and (4) to create a pleasant atmosphere while audiences receive and digest information (entertain).

We found that the most widely used medium for tourism promotion is online media. Ease of access and flexibility of online media make it capable to contain all required information to promote tourism. The internet can be used to promote visually (only in the form of text and images) and also in audio visual (such as video). This is the reason of the sampled existing models is focused on online media. Addition reason was the other media promotion, e.g. printed media is rarely found.

Many posts, articles, and videos found in internet about Malang indicated the enthusiasm of the community about the destination. The article is strongly diverse, e.g. post that contains personal experiences and even structured posts that aiming to attract tourists. The promotional models are websites, blogs, social networking and online video about tourism.

There are two indicators that detect the SWOT in this study. First, the performance of the previous model - used to find the most suitable promotional models as medium for advertising the tourism. Second, fit promotional model to lift Malang Raya's tourism that align with the concept of destination branding. The model can be formulated in a new shape of Malang tourism advertising to help stakeholders create a promotional model based on destination branding concept.

To compete with other tourist destination, Malang should have highlighted characteristics in the concept establishment of the destination branding. The concept of destination branding is a promised memorable travel experience that is uniquely associated with the destination object [5]. It means that the promotion of Malang Raya as the tourism destination branding should provide an overview of the unique tourism objects and any content that intersect with Malang Raya's tourism in universal packaging.

Related to the branding purposes, ads establish a right perception towards the minds of consumers, so that they can understand more about what is offered by a brand. Efforts to communicate the brand is promotional activities. Promotion as a tool of communication between 
producers and consumers is aimed to introduce the product, advantages, types, to detail that distinguishes the product with another product.

Tourism as a product is also treated similarly. Promotion of the destination should be focused on the target market segment when creating a brand [6]. It implies that the understanding on the target segment is essential. Tourism destination promotional model must include the required information for potential tourists. In addition, information should not only provide a reference, but also wrapped in an attractive packaging design, to keep attract the potential tourists.

Previous promotional activities was done over the internet as a series of efforts to inform unaware public on the tourism potential of Malang to become aware, and eventually attracted to the potential tourism object, and ended by decided to visit the attraction.

Promotional model with the concept of destination branding should also associate a brand to a geographic area with collected perceptions about the uniqueness [7]. All models that have been analyzed in this study have its own role to display Malang as a tourist destination area. However, the purpose of this research is to create an advertising model.

According to the source taken from the Handbook of Tourism and Destination Branding, advertising were lies on the initial level. It is only functioned as a trigger to make tourists interested to visit the tourism object [2] in Malang Raya. Therefore, the domain of this study did not recommend traveling action or discuss about what the ideal strategy in the mixed promotion to directly make potential tourists decide to visit the tourism object.

Related to that purposes, media that used to advertise must be a precise media which is able to change perception of audience as effectively as possible. It also needs to bring them to the level of their awareness on the diverse of Malang Raya's tourism potential objects.

\section{SWOT Analysis}

Four selected promotion through the internet media, i.e. websites, blogs, social networks, and videos were analyzed base on the strengths, weaknesses, opportunities and threats. Websites and blogs are very instrumental in giving detailed information about the tourism object, providing practical travel tips, transportation, and the plus or minus subjective opinion of the author. This kind of information is needed to convince potential tourists on a particular tourism object. In other words, this model is an advanced form of advertise. Thus, the model is no longer aimed to "introduce", but more to "convince" and "produce an action" in the form of traveling.

Unlike the websites and blogs, promotion through social network is a method of promotion which relatively less qualified to introduce tourism. Social networks mostly used to promote products by uploading photos, price lists and product details in simple way. If the product is replaced, the information different with the previous products detail.

It took a lot of detailed information to convince prospective tourists to visit the tourism object with the promise of an unique experience. Promoting tourism destinations means to build a psychological bond between potential tourists to these destinations [2].

Social network has limitations in showing the details in question. However, social network has its advantages to display the direct two-way communication that is not provided by any other promotional models. Prospective tourists can directly interact with the owners of social network account to resolve their curiosity. Nonetheless, communicate in social networks needs someone to have an account on the site previously.

From the four models that have been described, it was found that the video is the most suitable advertising medium. Advantages possessed by the video are the elements required by a travel destination to promote itself. Name, symbols, words, signs, and other explanations about the tourist destinations are summarized in the form of moving pictures and sound efficiently. Tourism video is able to represent the memorable travel experience to the audience through the moving pictures. Uniqueness in the video could give impression and get attention on tourism objects in their ads.

Characteristized simple video is considered the most suitable variable to introduce a product or service. Thus, video is chosen as to create a new model form of tourism advertising. Video have a high level of complexity in the making process compared to other promotional models. It takes time, concept, effort, and cost to produce brilliant videos. However, the video is still an excellent model Ads.

Further assessment on SWOT showed that well conceptualized ads in creating of video on Malang tourism were still rare. This is an opportunity, because later models of audio-visual 
advertisements is expected to be an example for concerned parties in conceptualizing the next Malang tourism ads.

\section{CONCLUSION}

SWOT analysis on the performance and application of the destination branding concept, found that each of the existing models have informed the elements needed to promote the tourism commodities. Thus, we did not find difficulty in making model of a new tourism promotion that based on destination branding.

The four existing models has its own role in promoting Malang Raya. However, websites, blogs, and social network includes detailed information needed to convince potential tourists in particular tourism object.

The most suitable model is the video for tourism advertise, because video is able to represent the promise of a memorable travel experience with the audience better with moving pictures.

\section{ACKNOWLEDGEMENTS}

Deep thanks presented by the authors to Dr. Bambang Dwi Prasetyo, M.Sc. and Dr. Nasution Zulkarnain, MS., and those who have helped this study.

\section{REFERENCES}

[1] Magazine of Kanjuruhan. 2013. Visit year of Malang Regency Tourism. Government of Malang Regency. Malang.

[2] Anholt, S. 2009. Handbook on tourism destinations branding. UNWTO. Spain.

[3] Murray, K.B. 1991. A test of services marketing theory: consumer information acquisition activities. Journal of Marketing 55 (1), 10-25.

[4] Rakhmat, J. 1999. Communication research method. Remaja Rosdakarya. Bandung

[5] Goeldner, C.R., Ritchie Jr.B. 2009. Tourism: principles, practices, philosophies, $9^{\text {th }} \mathrm{Ed}$. John Wiley and Sons. New Jersey.

[6] Murphy, L., Moscardo G., Benckendorff P. 2007. Using brand personality to differentiate regional tourism destinations. Journal of Travel Research 46.

[7] Buhalis, D. 2003. e-Tourism: Information Technology for Strategic Tourism Management. Pearson. London. 